\title{
INCREASED SECRETION OF PROGESTERONE FROM THE OVARY OF THE EWE DURING THE PREOVULATORY PERIOD
}

\author{
A. G. WHEELER, $*$ D. T. BAIRD, $\uparrow$ R. B. LAND AND \\ R. J. SGARAMUZZI $\dagger$ \\ A.R.C. Animal Breeding Research Organisation, King's Buildings, \\ West Mains Road, Edinburgh EH9 37Q, and \\ $\dagger M R C$ Unit of Reproductive Biology, 39 Chalmers Street, Edinburgh EH2 9ER
}

(Received 10th April 1975)

The new $\mathrm{CL}$ is formed from the granulosa cells of the preovulatory follicle. This process involves well-characterized changes in the morphology of the granulosa cells that are usually accompanied by an increase in progesterone secretion (functional luteinization). In many animals, morphological luteinization of the granulosa cells is apparent some hours before the rupture of the follicle (Baird et al., 1975). Functional luteinization at this time can be inferred from an increase in the concentration of progesterone in the peripheral plasma in women (Yussman \& Taymor, 1970). These changes are coincident with, and dependent on, the preovulatory surge of LH. Although the morphology of the granulosa cells in the ewe changes after the onset of oestrus and immediately before the rupture of the follicle (Bjersing et al., 1972), there has been no demonstration of the secretory capacity of these cells.

To facilitate the study of possible changes in the progesterone secretion rate, serial collections were taken of ovarian rather than jugular venous blood. Four Finnish Landrace cross and four pure-bred Tasmanian Merino ewes that had had the left ovary autotransplanted to a carotid-jugular skin loop in the neck (Goding et al., 1967) were used. These animals have persistent CL (Goding et al., 1967), the regression of which may be induced by the infusion of prostaglandin F-2 $\alpha$ (PGF-2 $\alpha$ ) into the ovarian arterial supply (Chamley et al., 1972), thereby synchronizing the preovulatory events.

The jugular vein and carotid artery were cannulated (McCracken et al., 1969) and PGF-2 $\alpha$ was infused at the rate of $40 \mu \mathrm{g} / \mathrm{hr}$ for $4 \mathrm{hr}$ into the ovarian arterial supply on thirteen occasions. Timed ovarian venous samples were collected and the ewes teased with rams to detect oestrus at intervals of $3 \mathrm{hr}$ starting about $24 \mathrm{hr}$ after the PGF-2 $\alpha$ infusion and continuing until about $36 \mathrm{hr}$ after the onset of oestrus. Teasing was discontinued when the ewe refused to stand to the ram on two consecutive occasions after showing oestrus.

Within 30 min of collection the blood was centrifuged and the plasma from each sample stored in aliquots at $-20^{\circ} \mathrm{C}$ until assayed. Progesterone and $\mathrm{LH}$ were measured by radioimmunoassay (Scaramuzzi et al., 1975; Carr \& Land,

* Present address : Department of Anatomy, Medical School, University of Birmingham, Birmingham B15 2TJ. 
1975). The secretion rates of progesterone were calculated from the progesterone concentrations, haematocrits (determined at intervals of $9 \mathrm{hr}$ ) and ovarian blood flow rates (Collett et al., 1973).

Nine infusions conducted during the breeding season resulted in luteal regression and subsequent oestrus. The secretion rate of progesterone (mean \pm S.E.) in this group fell from $7.06 \pm 1.28 \mu \mathrm{g} / \mathrm{min}$ before the infusion to $0.293 \pm$ $0.077 \mu \mathrm{g} / \mathrm{min} 36.2 \mathrm{hr}$ after the start of the infusion. Oestrus and a preovulatory surge of $\mathrm{LH}$ occurred $42 \cdot 7 \pm 4 \cdot 2 \mathrm{hr}$ and $57 \cdot 1 \pm 3 \cdot 8 \mathrm{hr}$ respectively after the start of the infusion of PGF-2 $\alpha$. In order to relate the events studied to the time of ovulation rather than the regression of the previous $\mathrm{CL}$, the samples were grouped in relation to the maximum $\mathrm{LH}$ concentration which has been shown to occur $24 \mathrm{hr}$ before ovulation (Cumming et al., 1971). The means of the concentrations of $\mathrm{LH}$ and progesterone, progesterone secretion rates, times of collections and the mean duration of oestrus are shown in Text-fig. 1(a).

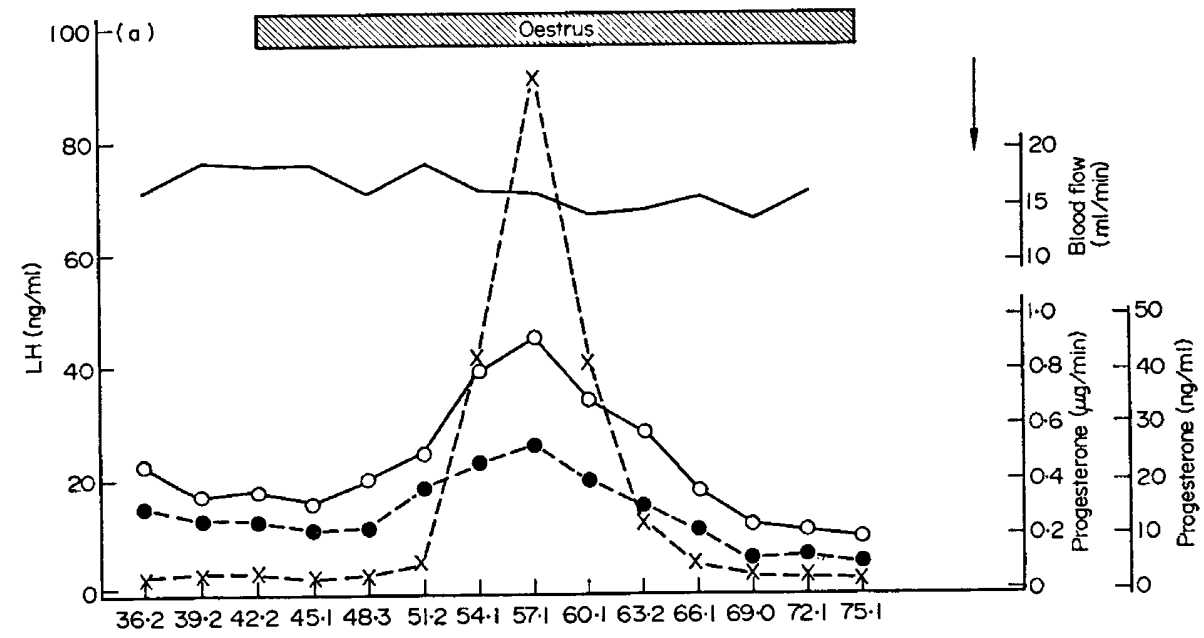

(b)
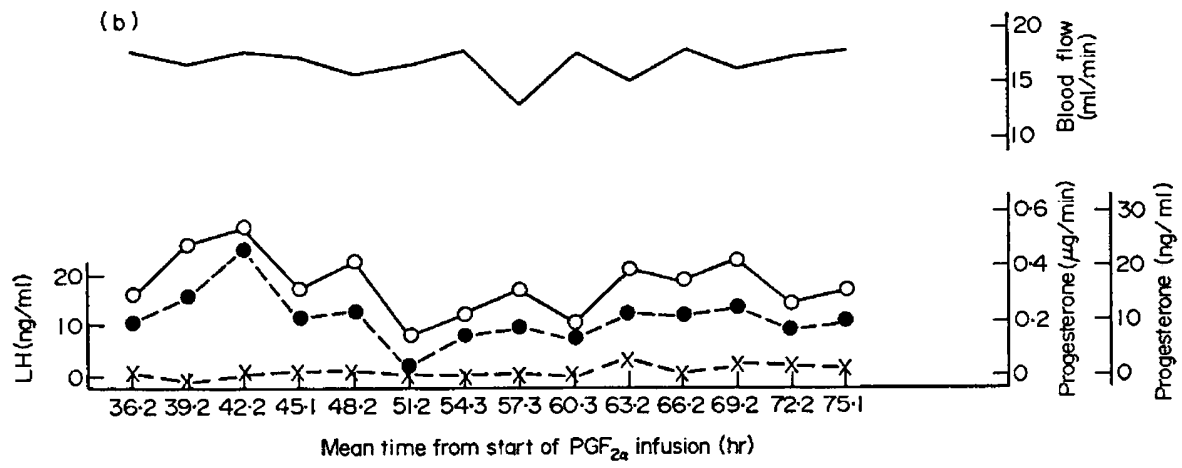

Text-Fig. 1. Mean concentrations of progesterone (0) and luteinizing hormone $(x)$, progesterone secretion rates $(O)$ and rates of blood flow $(\stackrel{-}{-})$ in ovarian venous plasma collected from sheep during (a) the preovulatory period during the breeding season $(n=9)$, and (b) during anoestrus $(n=4)$, after regression of the CL by PGF-2 $\alpha$ infusion. The estimated time of ovulation is indicated by the arrow. 
The progesterone secretion rate increased from $0.242 \pm 0.055 \mu \mathrm{g} / \mathrm{min}$ (from 36.2 to $48.3 \mathrm{hr}$ after the start of the PGF-2 $\alpha$ infusion) to a maximum of $0.52 \pm$ $0.12 \mu \mathrm{g} /$ min coincident with the peak concentration of LH $(57 \cdot 1 \mathrm{hr}$ after the PGF- $2 \alpha$ infusion), and subsequently decreased to $0.143 \pm 0.054 \mu \mathrm{g} / \mathrm{min}$ (from $66 \cdot 1$ to $75 \cdot 1 \mathrm{hr}$ after the PGF-2 $\alpha$ infusion). A comparison of the progesterone secretion rate during the $\mathrm{LH}$ peak $(54 \cdot 1,57 \cdot 1$ and $60 \cdot 1 \mathrm{hr}$ after infusion) with the three previous samples $(45 \cdot 1,48 \cdot 3$ and $51 \cdot 2 \mathrm{hr})$ indicated that the increase from a mean of $0.27 \mu \mathrm{g} / \mathrm{min}$ to a mean of $0.45 \mu \mathrm{g} / \mathrm{min}$ was statistically significant $(F<0.001)$.

Four infusions of PGF-2 $\alpha$ during mid-anoestrus induced luteal regression but were not followed by oestrus and changes in the $\mathrm{LH}$ concentration indicative of ovulation. These data are presented for comparison in Text-fig. 1(b), and the means of the LH concentrations, progesterone concentrations, progesterone secretion rates and rates of blood flow for the corresponding samples are also shown. Similar statistical analyses of the progesterone secretion rates to those performed on the experimental data showed that there was no significant variation, demonstrating that the previously described increase in the progesterone rate was not related to the PGF-2 $\alpha$ infusion per se.

The increase in the secretion rate of progesterone was small and transient compared with the preovulatory increase in the progesterone concentration in the woman (Johansson \& Wide, 1969). This difference may arise from the different patterns of the preovulatory LH surge, that of the sheep lasting for about $12 \mathrm{hr}$ while that of the woman persisting for 2 to 3 days.

There are five possible sources of this preovulatory progesterone: the ovarian stroma, the membrana granulosa and the theca interna of the Graafian follicle, the regressed CL, and any atretic follicles present. There is evidence that although the ovarian stroma of the sheep is not capable of secreting steroid hormones (Roche et al., 1974), the ovarian follicle can secrete progesterone in vitro (Moor, 1974) and has been suggested as the source of preovulatory progesterone in the woman (Johansson \& Wide, 1969). Ovine granulosa cells have also been shown to secrete progesterone in vitro (Seamark et al., 1974), and the secretion of progesterone at this time corresponds to the preovulatory changes in the structure and contents of the granulosa cells found by Bjersing et al. (1972). The regressing GL might be stimulated by, and have the capacity to respond to, the preovulatory LH surge.

With the preparation used in this study it was not possible to determine the source within the ovary of the preovulatory increase in the progesterone secretion rate that is coincident with the preovulatory surge in the $\mathrm{LH}$ concentration.

We wish to thank Miss Marjorie Fordyce and Mr Roger D. Preece for their help, Dr R. B. Snook for the equine (anti-bovine LH) antiserum, and Dr J. Pike (Upjohn Go.) for the prostaglandin F-2 $\alpha$.

\section{REFERENCES}

BaIRd, D.T., BAKER, T.G., MaNatTY, K.P. \& NeAL, P. (1975) Relationship between the secretion of the corpus luteum and the length of the follicular phase of the ovarian cycle. F. Reprod. Fert. 45, $611-619$. 
Bjsering, L., Hay, M.F., Kann, G., Moor, R.M., Naftolin, F., Scaramuzzi, R.J., Short, R.V. \& YoungLaI, E.V. (1972) Changes in gonadotrophins, ovarian steroids and follicular morphology in sheep at oestrus. F. Endocr. 52, 465-479.

CARR, W.R. \& LAND, R.B. (1975) Plasma luteinizing hormone levels and testis diameter of ram lambs of different breeds. F. Reprod. Fert. 42, 325-333.

Ghamley, W.A., Buckmaster, J.M., Gain, M.D., Cerini, J., Cerini, M.E., Cumming, I.A. \& Goding, J.R. (1972) The effect of prostaglandin $\mathrm{F}_{2 \alpha}$ on progesterone, oestradiol and luteinizing hormone secretion in sheep with ovarian transplants. J. Endocr. 55, 253-263.

Collett, R.A., LAND, R.B. \& BAird, D.T. (1973) The pattern of progesterone secretion by the autotransplanted ovary of the ewe in response to ovine luteinizing hormone. 7 . Endocr. 56, 403-411.

Gumming, I.A., Brown, J.M., Blockey, M.A. de B., Winfield, C.G., Baxter, R. \& Goding, J.R. (1971) Constancy of interval between luteinizing hormone release and ovulation in the ewe. $\mathcal{J}$. Reprod. Fert. 24, 134-135.

Goding, J.R., McGracken, J.A. \& Baird, D.T. (1967) The study of ovarian function in the ewe by means of a vascular autotransplantation technique. $\mathcal{F}$. Endocr. 39, 37-52.

Johansson, E.D.B. \& WIDE, L. (1969) Periovulatory levels of plasma progesterone and luteinizing hormone in women. Acta endocr., Copenh. 62, 82-88.

McCracken, J.A., Uno, A., Goding, J.R., Ichikawa, Y. \& Baird, D.T. (1969) The in vivo effects of sheep pituitary gonadotrophins on the secretion of steroids by the autotransplanted ovary of the ewe. F. Endocr. 45, 425-440.

Moor, R.M. (1974) The ovarian follicle of the sheep: inhibition of oestrogen secretion by luteinizing hormone. F. Endocr. 61, 455-463.

Roche, J.F., Karsch, F.J., Foster, D.L. \& Dziuk, P.J. (1974) Serum LH in ewes following sequential removal of ovarian follicles, corpora lutea and stroma. 7. Reprod. Fert. 40, 215-218.

Scaramuzzi, R.J., Corker, C.S., Young, G. \& Baird, D.T. (1975) Production of antisera to steroid hormones in sheep. In Steroid Immunoassay, pp. 111-122. Eds E.H.D. Cameron \& S.G. Hillier. Alpha Omega Alpha Publishing, Cardiff.

Seamark, R.F., Moor, R.M. \& McIntosh,J.E.A. (1974) Steroid hormone production by sheep ovarian follicles cultured in vitro. F. Reprod. Fert. 41, 143-158.

Yussman, M.A. \& TAYMOR, M.L. (1970) Serum levels of follicle stimulating hormone and luteinizing hormone and of plasma progesterone related to ovulation by corpus luteum biopsy. $\mathcal{F}$. clin. Endocr. Metab. 30, 396-399. 